\title{
УAK 331:658
}

С. В. Васильєв, к. е. н., доцент кафедри економіки, Аніпровський Аержавний аграрно-економічний університет, Україна ORCID ID: 0000-0002-4388-4091

А. О. Кривонос, к. е. н., професор кафедри менеАжменту, Аніпровський інститут Приватного акціонерного товариства "Вищий навчальний заклад "Міжрегіональна Академія Управління персоналом", Україна

ORCID ID: 0000-0002-9810-2018

\section{МЕТОАИ ПІАВИЩЕННЯ ЕФЕКТИВНОСТІ УПРАВАІННЯ ПІАПРИСМСТВ УКРАЇНИ В СУЧАСНИХ УМОВАХ}

\author{
S. Vasil'ev, \\ Ph. D. in Economics, Associate Professor of Economics Department \\ Dnipro State Agrarian and Economic University, Ukraine \\ A. Krivonos, \\ Ph. D. in Economics, Professor of Management Department, Dnepr institute of the Private joint-stock company \\ "Higher educational establishment "Interregional Academy of Management a personnel", Ukraine
}

\section{THE METHODS OF ENHANCE THE EFFECTIVENESS OF UKRAINE'S ENTERPRISES MANAGEMENT IN MODERN CONDITIONS}

Розглянуто основні положення методів підвищення ефективності управління підприємств України в сучасних умовах і на основі цього розрахунку чисельності управлінського персоналу.

Аосліджено, що Аля оцінки ефективності апарату управління підприємством, необхідно визначити завантаженість кожного управлінського підрозділу. Аля цього доцільним буде оцінювати ефективність управлінської праці за ії функціями, що дозволить більш обгрунтовано визначити, які фахівці потрібні Аля апарату управління і в якому управлінському підрозАілі є резерв.

Визначено, що кількісно оцінити вплив обсягів змістовного навантаження на ефективність управлінської праці на теперішній час не є можливим. В якості нульового приближення до оцінки цієї величини пропонується підхіА, що базується на порівняльній оцінці змістовного навантаження різних управлінських підрозділів, що функціонують у межах встановленого показника якості.

У статті пропонується визначити ефективність управління в залежності від обсягів змістовного навантаження на співробітників управлінських підрозділів у відносних величинах, що надасть можливість аналізувати діяльність підрозділів незалежно від їх спеціалізації.

Результатом застосування методики $є$ формування рекомендацій щодо удосконалення стратегії розвитку системи управління персоналом підприємства, що дадуть змогу зАійснювати контроль за оптимальною завантаженістю управлінських робітників; розрахувати оптимальну чисельність управлінських підрозділів; регулювати ефективність управлінської праці.

The main provisions of the enhance the effectiveness methods of Ukrainian enterprises management in modern conditions and the number of management personnel is based on this calculation are considered.

This requires the development of methodological provisions for optimizing the workload of the management units, which will promotes efficiency of management and reduce management costs. 
It is investigated that in order to assess the efficiency of enterprise management, it is necessary to determine the load capacity of each administrative unit.

For this purpose, it will be useful to assess the management effectiveness for its functions, which will allow more reasonably to determine what specialists are needed for the management and in which management unit has a reserve.

If the factor of time is taken as a criterion for the management functions classification, then they could be considered as successive stages of the implementation of managerial influence on the production process.

It is determined that it is not possible to quantify the impact of volumes of content load on the efficiency of managerial labor at the present time.

As a zero approximation to the estimation of this value, an approach based on a comparative assessment of the content load of various management units operating within the established quality index is proposed.

The indicator of the rhythm of work could be selected on the role of the normative quality indicator in this case.

In the article proposes to determine the management effectiveness according to the amount of content load on employees of administrative units in relative terms, which will enable the analysis of the activities of units, regardless of their specialization.

The organizational and economic mechanism for managing the company's efficiency that is proposed by authors has universal character and could applied to any enterprise of any branch of social production.

The result of the application of the method are to formulate recommendations for improving the strategy of development of the personnel management system of the enterprise, which will enable to control the optimal workload of the managerial workers; calculate the optimal number of administrative units; regulate the effectiveness of managerial work.

Ключові слова: підприємство, управління, економічна ефективність, змістовне навантаження в управлінні.

Key words: enterprise, management, economic efficiency, content management.

\section{ПОСТАНОВКА ПРОБЛЕМИ}

Аосягнення необхідного рівня конкурентоспроможності підприємств в Україні у разі входження в середовище вільного простору європейського ринку, що сформувався в умовах жорсткої політичної та економічної конкуренції, на тлі діючих європейських стандартів, конче потрібен відповідальний підхід у прийнятті того чи іншого методу корегування управлінської діяльності.

Прийнявши до уваги дійсне положення підприємств України в рейтингах європейських ринків, а також розбіжності концептуального плану, які склалися у наслідок історичної та геополітичної обстановки, треба відмітити слабкість вітчизняного управлінського персоналу в порівнянні з європейським. Безперечно результат менеджменту - це техніко-економічні показники підприємства. Навіть у цьому випадку на підприємстві у механізмах керування персоналом відсутні чіткі, а інколи й загальноприйняті методи підвищення ефективності управління. 3 огляду на вказане, суттєвого значення на сьогодні отримує підвищення ефективності управлінської праці.

\section{АНАЛІЗ ОСТАННІХ ДОСЛІДЖЕНЬ І ПУБЛІКАЦІЙ}

Проблематика ефективності процесу управління в умовах нестабільного як внутрішнього, так і зовнішнього середовища досліджена в наукових працях такими вченими: Б.М. Андрушків, І.О. Бланк, В.П. Галенко, Й.С. Завадський, I.I. Мазур, В.А. Шапіро, А.В. Шегда, В.В. Юрчишин, П. Арукер, Е. Мейо, К. Норт та іншими вітчизняними та зарубіжними науковцями. Аналіз наукових думок зазначених авторів дає підстави стверджувати, що єдиної точки зору щодо трактування та оцінювання ефективності управління досі не сформовано. Разом із тим збільшилася неоднозначність визначення ефективності управління та урізноманітнилися її показники оцінки.

\section{META CTATTI}

Метою статті $€$ пропозиція науково-обгрунтованого метода удосконалення системи управління на підприємствах. Це потребує розробки методичних положень оптимізації навантаження робітників управлінських підрозділів, що сприятиме підвищенню ефективності управ- 
Таблиця 1. Взаємозв'язок функцій, завдань управління та їх результатів

\begin{tabular}{|l|l|l|}
\hline \multicolumn{1}{|c|}{$\begin{array}{c}\text { Функції } \\
\text { управління }\end{array}$} & \multicolumn{1}{|c|}{ Завдання управління } & \multicolumn{1}{|c|}{$\begin{array}{c}\text { Результати виконання } \\
\text { функцій }\end{array}$} \\
\hline Планування & $\begin{array}{l}\text { Обгрунтування темпів } \\
\text { пропорційного кількісного і } \\
\text { якісного розвитку виробничої } \\
\text { системи }\end{array}$ & $\begin{array}{l}\text { Плани економічного, } \\
\text { соціального, науково- } \\
\text { технічного розвитку } \\
\text { виробництва }\end{array}$ \\
\hline Регулювання & $\begin{array}{l}\text { Створення стійкості, стабільності } \\
\text { виробництва }\end{array}$ & $\begin{array}{l}\text { Затвердження стандартів } \\
\text { і норм }\end{array}$ \\
\hline Координування & $\begin{array}{l}\text { Встановлення взаємозв'язку } \\
\text { підрозділів в системі виробництва, } \\
\text { маневрування ресурсами у } \\
\text { відповідності зі зміною завдань }\end{array}$ & $\begin{array}{l}\text { Затвердження графіків, } \\
\text { розпорядку роботи, } \\
\text { корегування планів }\end{array}$ \\
\hline Контроль & $\begin{array}{l}\text { Кількісна і якісна оцінка та облік } \\
\text { результатів дійсного стану справ. } \\
\text { Перевірка рішень, пов'язаних з } \\
\text { розвитком виробництва }\end{array}$ & $\begin{array}{l}\text { Рішення по результатам } \\
\text { обліку, перевірок, ревізії } \\
\text { тощо }\end{array}$ \\
\hline \multicolumn{2}{|l}{}
\end{tabular}

лінської праці і скороченню видатків на управління.

\section{РЕЗУЛЬТАТИ ДОСЛІДЖЕННЯ}

У науковій літературі розглядається багато підходів, як схожих між собою, так і зовсім різних, щодо оцінки ефективності управління. Основна причина існування такої їх різноманітності полягає в тому, що управління тісно пов'язане з усіма економічними та соціальними процесами, що відбуваються на підприємстві. На думку професора П. Березівського, ефективність виробничого сектору економіки лише на третину зумовлюється вкладеннями в техніку й устаткування, а все інше залежить від людського чинника, а саме інтелектуального потенціалу, кваліфікаційного рівня, здібностей керівників і спеціалістів [2]. Як стверджує професор Юрчишин В.В. [10], ще однією особливістю сучасного етапу розвитку системи управління є відсутність необхідної єдності нових форм організації виробництва і управління та ї змісту. Помітна питома вага управлінського персоналу свідчить про збереження на підприємствах практично незмінної структури системи управління, i, як наслідок, великої кількості закріплених за управлінцями зон контролю багатьох параметрів виробництва.

Систематизація існуючих підходів до оцінювання ефективності управління зроблена у праці Т. Коваленко [5] може бути також доповнена новими, що представлені в наукових працях інших авторів [1].

Окрім підходів до оцінювання ефективності управління, які були виділені Агатаєвою А.А., існують й інші методи оцінювання ефективності управлінської праці. Так, у праці $\Lambda$. Тараєвської пропонується визначати ефективність управління в залежності від обсягів змістовного навантаження [8]. Такий підхід в сучасній рин- ковій економіці набуває вирішального значення і потребує подальшого дослідження.

У статті пропонується визначити ефективність управління в залежності від обсягів змістовного навантаження на співробітників управлінських підрозділів. Реальний результат управлінської праці відображається в кінцевому рахунку в техніко-економічних показниках господарської діяльності в цілому. При отриманні заданих (або навіть покращених) показників доцільно говорити про достатньо високу ефективність управлінської праці. Однак навіть в такому випадку на підприємствах нерідко має місце нерівномірність навантаження управлінських підрозділів, що значно знижує ефективність управління. Причинами такого навантаження можуть бути неправильний розподіл робіт між підрозділами і нерівномірний розвиток підрозділів.

Таким чином, щоб оцінити ефективність апарату управління підприємством, необхідно визначити завантаженість кожного управлінського підрозділу.

Відомо, що діяльність апарату управління спрямована на те, щоб об'єднати всі функції управління. Отже, доцільним буде оцінювати ефективність управлінської праці за її функціями, що дозволить більш обгрунтовано визначити, які фахівці потрібні для апарату управління і в якому управлінському підрозділі $€$ резерв.

Управлінню притаманним є розподіл праці за функціями управління, тобто за ділянками управлінської діяльності, відокремленими під впливом як об'єкта управління виробництвом, так і закономірностями самого управління. Особливістю праці робітників апарату управління є велика питома вага розумових (творчих і логічних) операцій. Обсяг таких робіт пов'язаний зі змістовним навантаженням. 
Якщо в якості критерію класифікації функцій управління візьмемо фактор часу, то їх можна розглядати як послідовні етапи реалізації управлінського впливу (табл. 1). Отже, управлінську працю можна поділити на такі складові: $\mathrm{x}_{1}-$ планування, $\mathrm{x}_{2}-$ регулювання, $\mathrm{x}_{3}$ - координування, $\mathrm{x}_{4}$ - контроль.

Кожна функція здійснює вплив на інші функції і всі вони об'єднані в спільний процес управління. Отже, ефективність управління буде залежати від ефективності функціонування кожної із його складових. Тоді ефективність управління:

$$
\mathrm{E}_{\text {ф. упр }}=\mathrm{F}\left(\mathrm{x}_{1}, \mathrm{x}_{2}, \mathrm{x}_{3}, \mathrm{x}_{4}\right) \text {. }
$$

Вплив кожної складової функції управління на ефективність всього управління буде різним. На практиці має місце одночасне виконання підрозділом декілька функцій. Аослідження окремих функцій дає можливість зрозуміти сутність механізму управління, усунути залишкові ланцюги, підвищити ефективність діяльності апарату управління. Тому є доцільним визначити обсяги робіт підрозділів, пов'язаних зі здійсненням виконання ними функцій. Таке визначення може бути здійснено на основі експертних оцінок.

Аіяльність управляючого апарату в цілому і виконання кожної його функції складається під впливом різноманітних факторів, які здійснюють вплив на обсяг робіт управлінських підрозділів [2].

Попередній вибір факторів, що впливають на працеємкість робіт, здійснюється на основі логічного аналізу причин зміни працеємкості виконання окремих управлінських робіт. На цьому етапі для дослідження може застосовуватися велика кількість факторів, але вони повинні відповідати вимогам дієвості (здійснювати вплив на величину працеємкості робіт або відображати відмінності в техніко-організаційним умовам виконання робіт) і стабільності (не коливатися дуже різко по місяцям).

Вибір основних факторів дозволить вирішити важливу проблему - очистити основні показники управлінської праці від впливу другорядних явищ. Крім того, представлення єдиної якості як сукупності його складових має певні переваги. Набагато простіше дати оцінку по окремим критеріям. Якщо декілька експертів оцінюють вплив одного фактору, то можливо, що їх думки можуть розходитися. Практика показує, що ці розходження значно сильніші при оцінці впливу в цілому. При оцінці по окремим критеріям збіг точок зору експертів набагато більше, оскільки оцінка по окремому критерію не дуже складна і має більш чіткий зміст.
Визначення виробничих факторів та їх значимість в обсязі робіт управлінських підрозділів також можна оцінити методом експертних оцінок [7]. Експертам з числа провідних фахівців підприємства (начальників відділів, головних спеціалістів) пропонується перелік факторів, які можуть здійснювати вплив на складність та обсяги робіт управлінських підрозділів. При цьому слід зауважити, що серед найбільш істотних факторів можуть опинитися такі, між якими існує кореляція (наприклад, між чисельністю основних робітників і кількістю робочих місць). Такі фактори не повинні включатися у перелік для однієї і тієї ж функції управління.

Зростаючий обсяг управлінської роботи, який раніше виконувався завдяки збільшення кількості робітників у сфері управління, на сучасному етапі передбачає інший, більш раціональний шлях - підвищення ефективності праці робітників управління.

Враховуючи, що складність функцій управління неоднакова, тому різні і величини змістовного навантаження на управлінські підрозділи. Одним із головних факторів, що визначають зміст управління підприємством, $€$ взаємозв'язок його підрозділів. Цей зв'язок знаходить прояв у вигляді потоків інформації, яку підрозділи, що виконують функції управляння, використовують при прийнятті рішень і за допомогою якої передають управлінський вплив на виробництво.

Між обсягом інформації і складністю управління існує пряма залежність. Чим складніший процес управління, тим більший обсяг інформації, тим більша кількість управлінських робітників потрібна цьому виробничому об'єкту.

Метод визначення змістовного навантаження, що пропонується, заснований на використанні звітних кількісних показників. Зазвичай абсолютні значення факторів, що визначають кількість інформації і складність функції управління, представлені у непорівнянних величинах (обсяг продукції, серійність виробництва, норма витрачання матеріалів та ін.). Тому $є$ доцільним визначати обсяг змістовного навантаження на управлінські підрозділи у відносних величинах. Це надасть можливість аналізувати діяльність підрозділів незалежно від їх спеціалізації.

В основу цього методу покладений той факт, що управлінські підрозділи виконують одночасно декілька функцій управління. Причому, як це було зазначено вище, обсяги виконання цих функцій кожним підрозділом $є$ різними. 


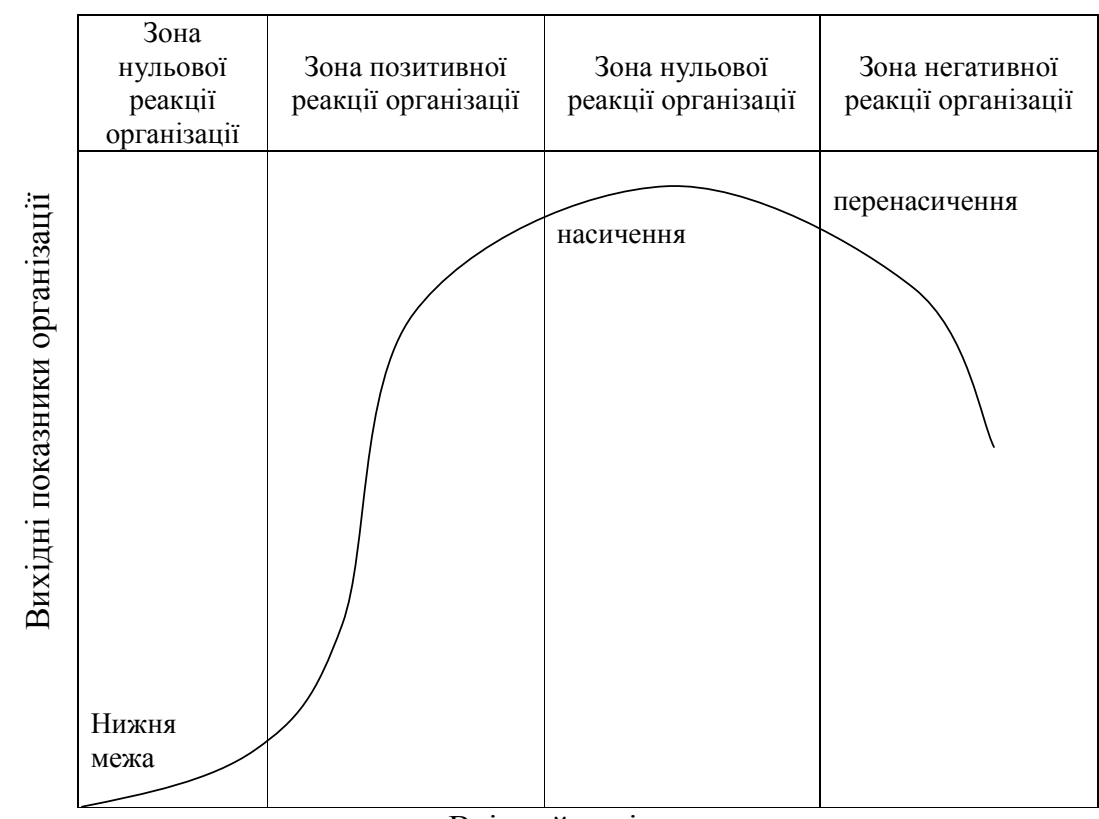

Вхідний потік

Рис. 1. Реакція організації на чисельність персоналу

Аля того, щоб визначити повний обсяг змістовного навантаження, необхідно спочатку визначити обсяг цього навантаження (K), зумовлений впливом кожного фактору окреMO:

$\mathrm{K}=\mathrm{P}_{\text {пит } 1, \mathrm{~g}} \times \mathrm{K}^{\prime}$

де $\mathrm{P}_{\text {пит } 1, \mathrm{~g}}$ - питома вага 1-ої функції управління в обсязі робіт g-го підрозділу;

$\mathrm{K}^{\prime}$ - коефіцієнт відносної участі.

$\mathrm{K}^{\prime}=1 / \mathrm{u}$,

де u - кількість підрозділів, для яких фактор, що розглядається, є визначальним.

Після вибору виробничих факторів і визначення окремих коефіцієнтів змістовного навантаження можна розрахувати повний коефіцієнт змістовного навантаження 1-ої функції управління.

$\mathrm{K}_{\Pi}=\Sigma \mathrm{K} \phi$

де $\mathrm{K}_{1}, \mathrm{~K}_{2}, \mathrm{~K}_{3}, \ldots \ldots ., \mathrm{K}_{\phi}$ - окремі коефіцієнти; ф- кількість факторів.

Підставив у формулу (1) значення окремих коефіцієнтів із формули (2), отримаємо наступну формулу розрахунку повного коефіцієнта змістовного навантаження для підрозділу по даній функції управління:

$\mathrm{K}_{\text {пg }}=\mathrm{P}_{\text {пит } 1, \mathrm{~g}} \times \mathrm{K}_{1}^{\prime}+\mathrm{P}_{\text {пит } 1, \mathrm{~g}} \times \mathrm{K}_{2}^{\prime}+\ldots+\mathrm{P}_{\text {пит } 1, \mathrm{~g}} \times \mathrm{K}_{\phi}^{\prime}$.

Метод визначення змістовного навантаження дозволяє шляхом нескладних розрахунків визначити відносну завантаженість управлінських підрозділів.

Повний коефіцієнт змістовного навантаження по всім функціям, що виконуються g-им підрозділом, тобто його повне змістовне навантаження:
$\mathrm{Ng}=\Sigma \mathrm{K}_{\mathrm{ng} 1,} 1=1,2,3,4$,

де $\mathrm{Ng}$ - повне змістовне навантаження $g$ го підрозділу;

$\mathrm{K}_{\mathrm{g}}$ - повний коефіцієнт змістовного навантаження g-го підрозділу по $l$-й функції управління.

Кількісно оцінити вплив обсягів змістовного навантаження на ефективність управлінської праці на теперішній час не $є$ можливим. В якості нульового приближення спробуємо визначити загальний характер такої залежності на основі концептуальних уявлень.

Відомо, що при дуже низькому навантаженні ефективність наближується до нулю. Поперше, це пов'язано з тим, що людина яка знаходиться на роботі, так чи інакше витрачає весь свій час безповоротно і якщо за цей час вирішується дуже мало управлінських завдань, то ефективність $\dddot{1} є є$ низькою. По-друге, при дуже низькому навантаженні вступають у дію психологічні фактори: людина втрачає інтерес до роботи, відчуття відповідальності, професіоналізм і в кінці кінців виконує дуже погано навіть те, що йому доручено.

3 іншого боку, зрозуміло, що при високих навантаженнях людина не встигає справлятися з усіма завданнями і починає вирішувати їх по спрощеному алгоритму (по аналогії, за натхненням), не особливо вникаючи в їх специфіку. Чим вищим буде навантаження, тим більший відсоток таких завдань, які вирішуються неадекватними методами. Таким чином, людина звикає до подібного стилю, у неї атрофується відчуття відповідальності, втрачається істин- 
ний професіоналізм і замість цього формується так званий "професіоналізм" бюрократичний - здатність швидко "відмовитися" від будьякого складного запитання. В результаті не вирішується по справжньому навіть той невеликий відсоток завдань, який міг би бути вирішений на достатньо високому рівні.

Отже, при занадто високих змістовних навантаженнях ефективність також, як і при занадто низьких, наближується до нулю (рис. 1). 3 цього можна зробити висновок, що існує таке навантаження, яке відповідає максимальній ефективності, яку можна вважати оптимальною.

Наведене вище непрямо підтверджується даними досліджень закордонних вчених, в яких показана залежність загального ефекту, що досягає організація, від чисельності персоналу [4]. Оскільки при фіксованому обсязі завдань зростання чисельності є адекватним зниженню змістовного навантаження, то це співпадає з тенденцією побудованою на основі загальних концептуальних уявлень.

Питання масштабування кривої, представленої на рисунку 1 , тобто прив'язка її до конкретних величин навантаження та ефективності і визнання конкретного значення оптимального навантаження залишається поки що відкритим. У цій статті в якості нульового приближення до оцінки цієї величини пропонується підхід, що базується на порівняльній оцінці змістовного навантаження різних управлінських підрозділів, що функціонують в межах встановленого показника якості. На роль нормативного показника якості може бути вибраний показник ритмічності роботи. В такому випадку в управлінських підрозділах, які ритмічно функціонують, питоме змістовне навантаження близьке до оптимального, буде мати те, в якому це навантаження $€$ найбільшим. Слід підкреслити, що це буде справедливим за умови збереження ритмічності роботи. Якщо питоме змістовне навантаження перевищить оптимальне, то у відповідності до кривої на рисунку 1 , ефективність роботи повинна знизитися, і це, зазвичай, в першу чергу відобразиться на ритмічності роботи.

Якщо визначене таким чином питоме змістовне навантаження прийняти в якості оптимального, то логічно поставити завдання вирівнювання змістовного навантаження між окремими управлінськими підрозділами. Одним 3 ефективних способів такого вирівнювання $€$ перерозподіл чисельності управлінських підрозділів.

Обгрунтованою є така чисельність робітників апарату управління і окремих його ланцюгів, яка забезпечує повне завантаження кож- ного робітника упродовж року і можливість якісного і своєчасного виконання робіт.

Оптимізація чисельності, на наш погляд, може бути досягнута шляхом находження нормованого співвідношення між чисельністю робітників за всіма функціями управління на основі оптимальної величини обсягу змістовного навантаження. Аля цього здійснюються розрахунки на основі питомого оптимального змістовного навантаження базових підрозділів підприємств. Базовий підрозділ вибирається наступним чином:

1) зі всіх підрозділів відбираються ті, які функціонують ритмічно, всі інші підрозділи в подальшому аналізу участі не прияють;

2) з вибраних підрозділів базовим приймається той, в якому питоме змістовне навантаження буде найбільшим.

При цьому чисельність управлінських підрозділів підприємства, що мають величину питомого змістовного навантаження нижче базового рівня, повинна зменшуватися. Це приведе до збільшення обсягу змістовного навантаження на кожного робітника підрозділу і, відповідно, підвищить ефективність праці.

Таким чином, ситуацію, коли за відсутності норм для управлінських робіт на однакових підприємствах і в однакових управлінських підрозділах є різна кількість робітників управління, усувається. Зміною чисельності управлінських підрозділів можна зробити однаковою завантаженість робітників управління в аналогічних підрозділах різних підприємств.

\section{вИСнОВки}

1. Розподіл процесу праці управлінських підрозділів на складові функції управління, які визначаються як послідовні етапи реалізації управлінського впливу, надає можливість здійснити оцінку завантаженості управлінських підрозділів.

2. Обсяг роботи і чисельність управлінських підрозділів залежать від багатьох виробничих факторів, які визначають потужність виробництва. Вплив цих факторів знаходить прояв у вигляді обсягів змістовного навантаження як непрямого відображення обсягу інформації і обсягу роботи апарату управління.

3. Залежність ефективності управлінської праці від обсягів змістовного навантаження знаходить вираз у вигляді кривої колообразного типу.

4. Визначення обсягу змістовного навантаження дозволить:

- здійснювати контроль за оптимальною завантаженістю управлінських робітників, 
- розрахувати оптимальну чисельність управлінських підрозділів, праці.

- регулювати ефективність управлінської

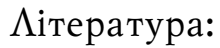

1. Агатаева А.А. Управленческие решения, которые типичны для функций менеджмента / А.А. Агатаева // Materialy XII mezinarodni vedecko - praktika conference. - Praha.: Publishing House "Education and Science" s.r.o., 2016. - s. 33-35.

2. Березівський П.С. Організація виробництва і підприємницької діяльності в аграрних формуваннях: навч. посібник / П.С. Березівський, Ю.Е. Губені, Н.І. Михалюк: за ред. П.С. Березівського. - - ьвів: Укр. Технології, 2002. $-536 \mathrm{c}$.

3. Гудзій 3.М. Впровадження вартісноорієнтованого управління як елемент підготовки компанії до виходу на європейські ринки капіталу / 3.M. Гудзій // Матеріали IV всеукраїнської науково-практичної Інтернет-конференції. ційної академії, 2015. - С. 71-73.

4. Исследование операций. Т. 2. Модели и применения / Под ред. Аж. Моудера, С. Элмагради: Пер. с англ. Под. ред. И.М. Макарова, И.М. Бескровного. - М.: Мир, 1981. - 677 с.

5. Коваленко Т. Система показників комплексної оцінки управління персоналом/ Т. Коваленко // [Електронний ресурс]. - Режим доступу: http://ea.donntu.edu.ua/bitstream/ 123456789/14912/1/тернополь $1 . p d f$

6. Кривонос А.О., Прокопенко Ю.О. Адаптація менеджменту підприємств сучасної України в умовах європейської інтеграції/ А.О. Кривонос, Ю.О. Прокопенко // Materialy XII mezinarodni vedecko - praktika conference. Praha.: Publishing House "Education and Science" s.r.o., 2016. - S. 34-37.

7. Аепа Р.Н. Влияние качества управленческих решений на эффективность функционирования предприятия/P.Н. Аепа [Електронний ресурс].Режим доступу: http://dspace.nbuv.gov.ua/ bitstream/handle/123456789/2943/St_34_13.pdf

8. Тараєвська $\Lambda$., Ріщук $\Lambda$. Методичні підходи до оцінки рівня управління організацією / $\Lambda$. Тараєвська, $\Lambda$. Ріщук // Економічний аналіз. - 2013. - T. 12 (4). - С. 79-83.

9. Щекин Г.В. Теория и практика управления персоналом: учеб. метод. пособ. - 2-е изд. — К.: МАУП, 2007. - 208 с.

10. Юрчишин В.В. Науково-методологічні та організаційні основи розвитку систем управ- ління аграрним сектором економіки / В.В. Юрчишин // Економіка АПК. - 2003. - № 1. C. $17-25$.

\section{References:}

1. Ahataeva, A.A. (2016), "Management decisions that are typical of management functions", Materialy XII mezinarodni vedecko - praktika conference, Praha: Publishing House "Education and Science, pp. 33-35.

2. Berezivskiy, P. Gubeny, Yu. and Muyhalyuk, N. (2002), Orhanizatsiia vyrobnytstva i pidpryiemnyts'koi diial'nosti v ahrarnykh formuvanniakh [Organization of production and entrepreneurial activity in the agrarian forming], Ukr. Tekhnolohii, L'viv, Ukraine.

3. Hudzij, Z.M. (2015), "The introduction of value-oriented management as an element of preparation for the company to enter the European capital markets", Materialy IV vseukrains'koi naukovo-praktychnoi Internet-konferentsii [Conference proceedings of IV Ukrainian scientific and practical Internet-conference], Lviv, Ukraine, pp. 71-73.

4. Moder, Joseph J. and Elmaghraby, Salah E. (1981), Operations Research. Models and Applications, Moscow, Mir, 677 p.

5. Kovalenko, T. (2011), "System of indicators of integrated assessment of personnel management" [Online], availableat: http://ea.donntu.edu.ua/bitstream/123456789/14912/1/ тернополь1.pdf (Accessed 30 March 2019).

6. Kryvonos, A.O. and Prokopenko, Yu.O. (2016), "Adaptation of management of enterprises of modern Ukraine in conditions of European integration", Materialy XII mezinarodni vedecko - praktika conference [Conference proceedings of XII international scientific and practical conference], Praha.: Publishing House 'Education and Science" s.r.o., pp. $34-37$.

7. Lepa, R.N. (2006), "The impact of quality management decisions on the enterprises' efficiency" [Online], available at: http://dspace.nbuv.gov.ua/bitstream/handle/123456789/2943/ St_34_13.pdf (Accessed 12 April 2019).

8. Taraievs'ka, L. and Rischuk, L. (2013), "Methodological approaches to assessing the level of management of an organization", Ekonomichnyj analiz, vol. 12 (4), pp. 79-83.

9. Schekyn, H.V. (2007), "Theory and practice of personnel management", Kyiv, MAUP, 208 p.

10. Yurchyshyn, V.V. (2003), "Scientific, methodological and organizational foundations for the development of agrarian sector management systems", Ekonomika APK, vol. 1, pp. 17-25. Стаття надійшла до редакиії 02.05.2019 p. 